\section{Analysis of financial resources for public health in Brazilian capitals: a time trend ecological study}

\author{
Análise de recursos financeiros para saúde \\ pública nas capitais brasileiras: um estudo \\ ecológico de tendências temporais
}

\begin{abstract}
Análisis de recursos financieros para la salud pública en capitales brasileñas: un estudio ecológico de tendencia temporal
\end{abstract}

Vinícius Henrique Ferreira Pereira de Oliveira 1 Millena Barroso Oliveira 1

Cauane Blumenberg 2

Álex Moreira Herval 1

Luiz Renato Paranhos 1

\begin{abstract}
This study aimed to analyze part of the financial resources used to fund public health actions in the 26-Brazilian capitals, from 2008 to 2018. This is a time-trend ecological study involving revenue and expenditure indicators provided by the Information System on Public Budget for Health (SIOPS). The values were deflated based on the Extended National Consumer Price Index of 2018 in Brazil to allow the comparison over the years. The mean annual variation of health investments, in Brazilian Reais (BRL) was assessed using linear regressions. Pearson's correlation coefficients were estimated between federal revenues and expenditures with the capitals' resources. All capitals presented statistically significant positive correlations for the origin of the budget resource invested in health. The lowest coefficient was found in the capital city of Macapá (Amapá State) $(r=0.860)$ and the highest, in Fortaleza (Ceará State) $(r=0.997)$. Belo Horizonte (Minas Gerais State) was the capital with the highest annual increase in federal transfers (about BRL 67.91 per year) and Teresina (Piaui State) presented the highest annual increase in health expenditures among the capitals (about BRL 55.42 per year). We found a increase in the transfers of the Brazilian Unified National Health System (SUS) and municipal resources in almost all capitals, but there are still inequalities in the distribution of financial resources among Brazilian capitals from different regions. Health funding is affected by the municipalization of SUS and it is not the single factor affecting the access and quality of health services.
\end{abstract}

Investiments; Quality of Health Care; Unified Health System

\author{
Correspondence \\ L. R. Paranhos \\ Faculdade de Odontologia, Universidade Federal de Uberlândia. \\ Av. Pará 1720, Bloco 2G, sala 1, Uberlândia, MG 38405-320, \\ Brasil. \\ paranhos.lrp@gmail.com \\ 1 Universidade Federal de Uberlândia, Uberlândia, Brasil. \\ 2 Universidade Federal de Pelotas, Pelotas, Brasil.
}




\section{Introduction}

In the light of the Brazilian health reform movement, the Brazilian Unified National Health System (SUS) was created aiming at universalizing health, which is understood as a civil right and therefore a duty of the State 1,2. To fund the national health policy in Brazil, it was defined that SUS's financial resources would originate from the budgets of social security and federal, state, and municipal governments, as well as other sources granted by law 3. Although SUS funding derives from different budget sources, the history of SUS is still marked by insufficient funding 4 .

The composition of the total resources shared between federal, state, and municipal governments composes a funding system with criteria that are still not sufficiently established 5 . As a result, Brazil still faces an unequal distribution of health resources 6,7,8,9,10,11. Thus, ensuring universal, integral, and good quality public health to Brazilian citizens is a challenge 4,12 .

Although the cities are mainly responsible for offering public health actions and services to their populations 13 , federal funding plays an essential role to make public health feasible. Thus, differences in the capability to collect funding from municipal taxes, along with variations in the transfer of resources to SUS 10,11, emphasize inequalities in the quality and offer of health care to the population in cities from the same region.

Considering the reducing trend of the public budget induced by austerity policies and the current concentration of studies about public health funding in metropolitan regions and small cities in Brazil $6,7,8,9,10,11$, this study analyzes part of the financial resources (federal and municipal/capital funding) for public health actions in the 26-Brazilian capitals, from 2008 to 2018, and verifies the proportion of the budget composed of federal revenues and expenditures with the capitals' resources.

\section{Methods}

A time-trend ecological study was performed according to the guidelines of the Strengthening the Reporting of Observational Studies in Epidemiology (STROBE) 14 checklist. The data were obtained from the Information System on Public Budget for Health (SIOPS) 15, which is maintained by the Brazilian Health Informatics Department (DATASUS). The data available in the SIOPS platform is compulsorily informed by each government instance (declaratory data). This study was not subject to ethical assessment because it used secondary data of public domain, in agreement with Resolution $n$. 510 of April 7, 2016, of the Brazilian National Health Council.

This study analyzed part of the public health budget indicators, including health funding from federal and municipal resources. There are other important sources of financing in the composition of the public budget for health, but they were not considered in this analysis. The SIOPS also provides the total health expenditures for each Brazilian capital (including federal, municipal, and payments made with other funds not exclusive of the municipalities). Federal resources were divided by the total health expenditures in order to identify the proportion of the total health expenditures funded by the federal revenue. The outcomes were collected as gross values in Brazilian Reais (BRL) for each of the analyzed years (from 2008 to 2018). The 26-Brazilian capitals were analyzed in the study. Brasília, the Federal District capital, was not included in the analysis due to its absence in the SIOPS platform.

The variation of revenues and expenditures over the years may occur simply because of inflation, which may compromise the comparison of values from different periods. To correct this problem and allow the comparison among different years, the values were deflated based on the Extended National Consumer Price Index (INPC) 16 of 2018 (last year considered in the analysis) in Brazil. After deflated, the values were divided by the population living in the municipalities in each of the years analyzed to calculate the per capita values and allow comparing the cities with different population sizes.

The mean annual variations of the revenues from federal transfers and expenditures with the capitals' resources, in BRL, and per capita, were estimated using linear regressions. Pearson's correlation coefficients were used to estimate the correlation between both variables. All analyses considered a 5\% significance level and were performed using the Stata 16.1 software (https://www.stata.com). 


\section{Results}

The 26-Brazilian state capitals were included in the study, representing an estimated population of 45,737,596 inhabitants 17, and including 5,226 health facilities (Table 1).

In 2008, the SUS transfer values per inhabitant ranged between BRL 22.30 (Manaus, Amazonas State) and BRL 174.58 (Belo Horizonte, Minas Gerais State) (Figure 1a). In 2018, these values ranged between BRL 19.81 (Macapá, Amapá State) and BRL 919.68 (Cuiabá, Mato Grosso State). Belo Horizonte was the capital with the highest SUS transfer values per inhabitant in most of the 11 years. Regarding health expenditures paid with the municipal resources, in 2008, Salvador (Bahia State) was the capital with the lowest expenditures per inhabitant (BRL 44.80), whereas Vitória (Espírito Santo State) had the highest expenditures (BRL 219.89) (Figure 1b). In 2018, the lowest per capita expenditures were found in Macapá (BRL 120.17) and the highest in Teresina (Piauí State) (BRL 655.08).

\section{Table 1}

Characterization of Brazilian capitals regarding their state, region of the country, estimated population, and the number of health facilities. Brazil, 2018.

\begin{tabular}{|c|c|c|c|}
\hline Region/State & Capital & Estimated population & Health facilities \\
\hline \multicolumn{4}{|l|}{ Northeastern } \\
\hline Acre & Rio Branco & 401,155 & 95 \\
\hline Amapá & Macapá & 493,634 & 79 \\
\hline Amazonas & Manaus & $2,145,444$ & 363 \\
\hline Pará & Belém & $1,485,732$ & 168 \\
\hline Rondônia & Porto Velho & 519,513 & 99 \\
\hline Roraima & Boa Vista & 375,374 & 71 \\
\hline Tocantins & Palmas & 291,855 & 90 \\
\hline \multicolumn{4}{|l|}{ Northern } \\
\hline Alagoas & Maceió & $1,012,38$ & 148 \\
\hline Bahia & Salvador & $2,857,329$ & 367 \\
\hline Ceará & Fortaleza & $2,643,247$ & 187 \\
\hline Maranhão & São Luís & $1,094,667$ & 100 \\
\hline Paraíba & João Pessoa & 800,323 & 208 \\
\hline Pernambuco & Recife & $1,637,834$ & 274 \\
\hline Piauí & Teresina & 861,442 & 181 \\
\hline Rio Grande do Norte & Natal & 877,640 & 149 \\
\hline Sergipe & Aracaju & 648,939 & 115 \\
\hline \multicolumn{4}{|l|}{ Central-Western } \\
\hline Goiás & Goiânia & $1,495,705$ & 327 \\
\hline Mato Grosso & Cuiabá & 607,153 & 145 \\
\hline Mato Grosso do Sul & Campo Grande & 885,711 & 123 \\
\hline \multicolumn{4}{|l|}{ Southeastern } \\
\hline Espírito Santo & Vitória & 358,267 & 86 \\
\hline Minas Gerais & Belo Horizonte & $2,501,576$ & 328 \\
\hline São Paulo & São Paulo & $12,176,866$ & 678 \\
\hline Rio de Janeiro & Rio de Janeiro & $6,688,927$ & 257 \\
\hline \multicolumn{4}{|l|}{ Southern } \\
\hline Paraná & Curitiba & $1,917,185$ & 253 \\
\hline Rio Grande do Sul & Porto Alegre & $1,479,101$ & 201 \\
\hline Santa Catarina & Florianópolis & 492,977 & 134 \\
\hline
\end{tabular}

Source: Brazilian Institute of Geography and Statistics 17. 
Figure 1

Variation of federal resource transfers and municipal resources per inhabitant/year in Brazilian capitals, $2008-2018$.

1a) Variation of federal resource transfers

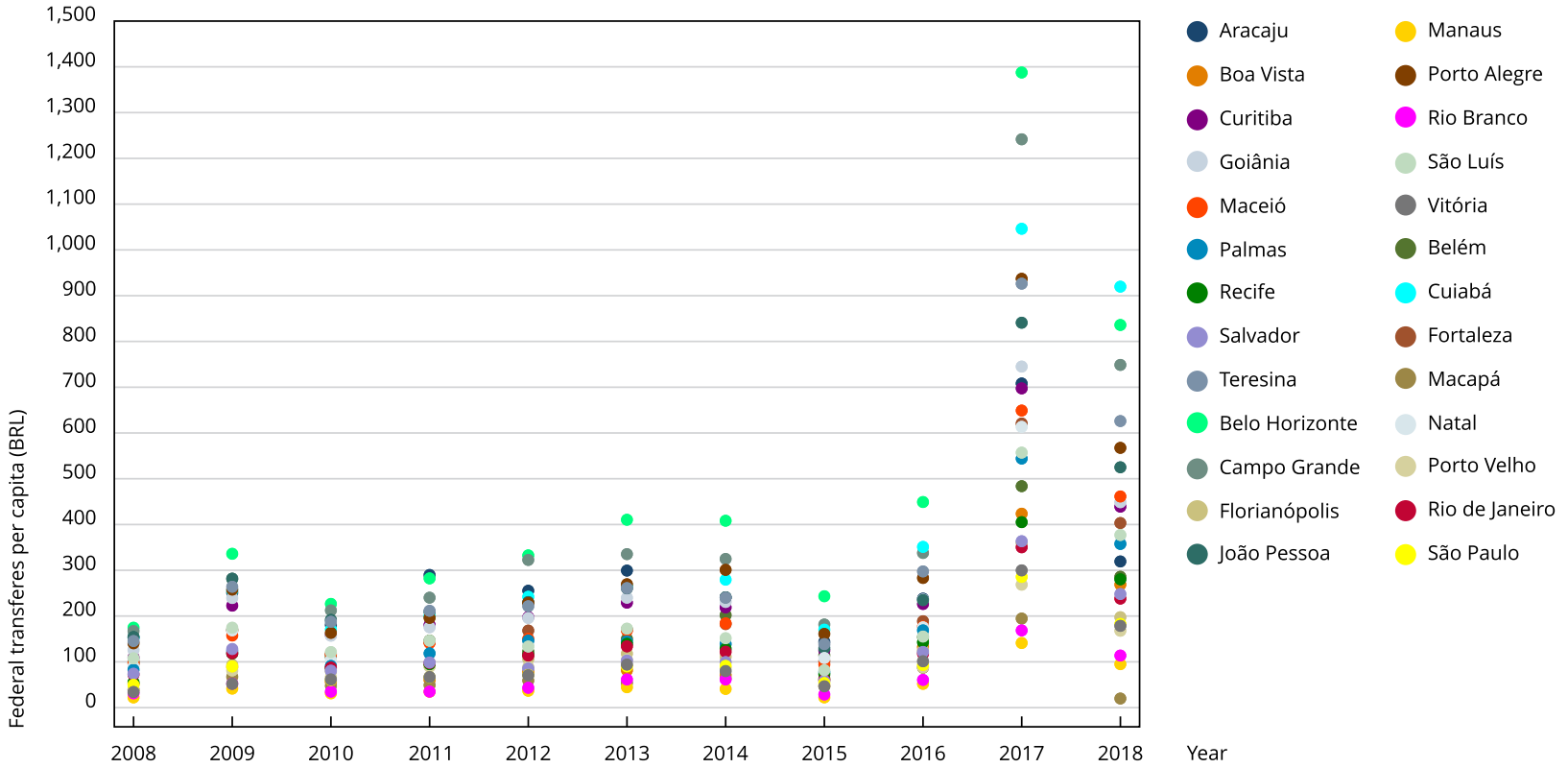

1b) Variation of municipal resources per inhabitant/year

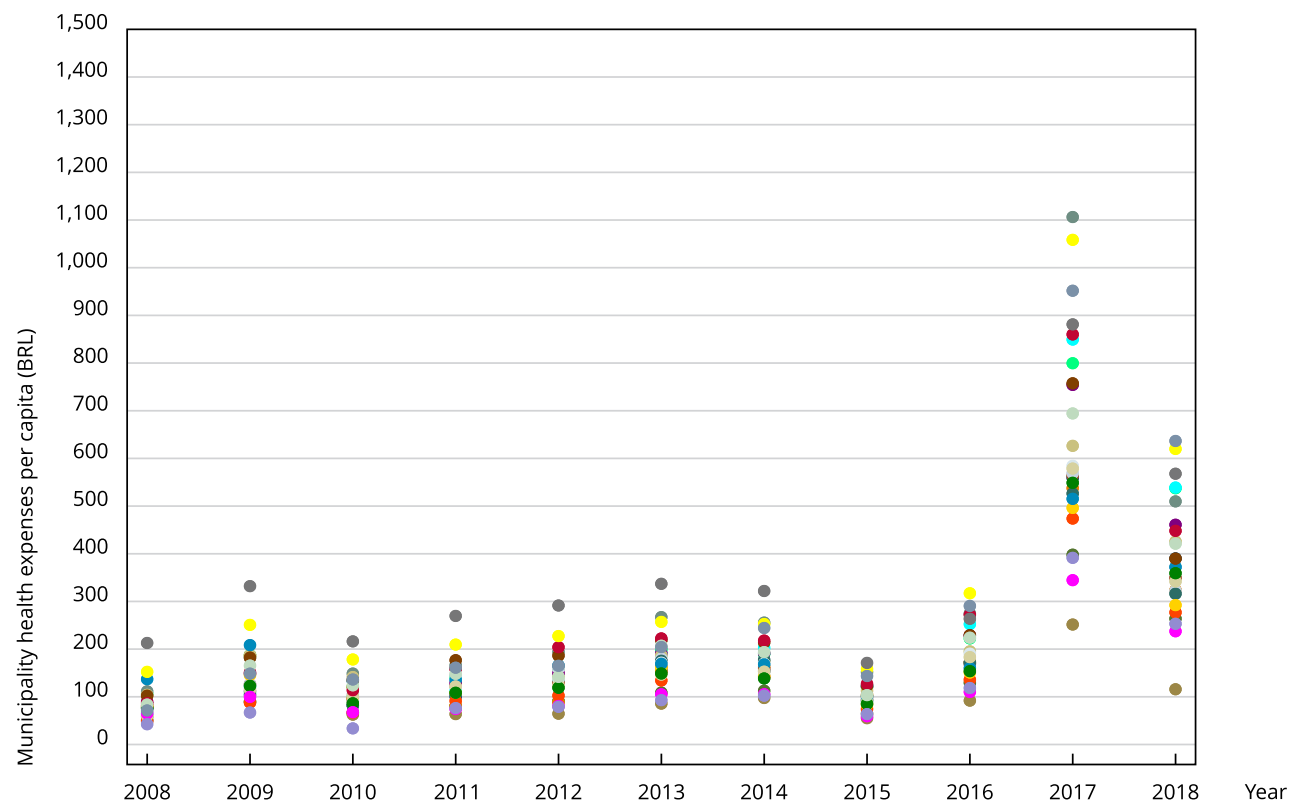


We observed that both initially analyzed indicators (revenues from federal transfers and expenditures with municipal resources) showed a significant annual increase, in Brazilian reais, for almost all Brazilian capitals (Table 2). Aracajú (Sergipe State) and Macapá were the only capitals in which SUS revenues remained constant from 2008 to 2018. The highest annual increase was observed in Belo Horizonte, where federal transfers increased an average of BRL 67.91 per inhabitant/year (95\%CI: 19.87; 115.95). As for health expenditures paid with the capitals' resources, Palmas (Tocantins State) and Vitória did not present increases or reductions over the years. The highest annual increase in health expenditures by municipal resources was found in Teresina, with BRL 55.42 per inhabitant/ year (95\%CI: 20.26; 90.59) (Table 2).

Table 2

Annual variation of the health revenue from federal transfers (per capita) and health expenditures committed by the cities (per capita). Brazil, 2008-2018.

\begin{tabular}{|c|c|c|c|c|c|c|}
\hline \multirow[t]{2}{*}{ Capital (State) } & \multicolumn{3}{|c|}{$\begin{array}{l}\text { Federal transfer revenue } \\
\text { per inhabitant }\end{array}$} & \multicolumn{3}{|c|}{$\begin{array}{l}\text { Health expenditures committed by the city } \\
\text { per inhabitant }\end{array}$} \\
\hline & Annual variation & $95 \% \mathrm{Cl}$ & p-value & Annual variation & $95 \% \mathrm{Cl}$ & p-value \\
\hline Aracaju (SE) & 21.54 & $-3.29 ; 46.37$ & 0.082 & 30.61 & $10.25 ; 50.96$ & 0.007 \\
\hline Belo Horizonte (MG) & 67.91 & $19.87 ; 115.95$ & 0.010 & 41.18 & $10.28 ; 72.09$ & 0.014 \\
\hline Belém (PA) & 19.12 & $2.66 ; 35.58$ & 0.027 & 20.50 & $5.93 ; 35.07$ & 0.011 \\
\hline Boa Vista (RO) & 20.84 & $4.13 ; 37.54$ & 0.019 & 22.81 & $1.97 ; 43.66$ & 0.035 \\
\hline Campo Grande (MS) & 57.16 & $11.50 ; 102.81$ & 0.019 & 50.74 & $7.93 ; 93.55$ & 0.025 \\
\hline Cuiabá (MT) & 61.36 & $20.82 ; 101.90$ & 0.007 & 48.67 & $16.89 ; 80.45$ & 0.007 \\
\hline Curitiba (PR) & 30.06 & $5.56 ; 54.56$ & 0.021 & 38.74 & $10.69 ; 66.79$ & 0.012 \\
\hline Florianópolis (SC) & 17.07 & $5.01 ; 29.13$ & 0.010 & 29.48 & $6.38 ; 52.58$ & 0.017 \\
\hline Fortaleza (CE) & 28.52 & $6.17 ; 50.86$ & 0.017 & 27.92 & $7.38 ; 48.46$ & 0.013 \\
\hline Goiânia (GO) & 31.11 & $4.64 ; 57.58$ & 0.026 & 26.74 & $5.87 ; 47.61$ & 0.017 \\
\hline João Pessoa (PB) & 34.15 & $2.91 ; 65.39$ & 0.035 & 26.91 & $8.80 ; 45.02$ & 0.008 \\
\hline Macapá (AP) & 4.76 & $-3.11 ; 12.63$ & 0.207 & 9.11 & $0.27 ; 17.94$ & 0.045 \\
\hline Maceió (AL) & 32.11 & $7.72 ; 56.50$ & 0.015 & 24.45 & $7.26 ; 41.65$ & 0.010 \\
\hline Manaus (AM) & 6.58 & $1.59 ; 11.57$ & 0.015 & 22.13 & $3.99 ; 40.27$ & 0.022 \\
\hline Natal (RN) & 27.21 & $4.38 ; 50.04$ & 0.024 & 31.08 & $10.33 ; 51.84$ & 0.008 \\
\hline Palmas (TO) & 25.50 & $5.42 ; 45.58$ & 0.018 & 19.87 & $-0.06 ; 39.80$ & 0.051 \\
\hline Porto Alegre (RS) & 42.50 & $9.16 ; 75.83$ & 0.018 & 33.42 & $5.76 ; 61.08$ & 0.023 \\
\hline Porto Velho (RR) & 11.80 & $2.54 ; 21.07$ & 0.018 & 29.63 & $8.63 ; 50.64$ & 0.010 \\
\hline Recife (PE) & 20.24 & $6.37 ; 34.11$ & 0.009 & 27.40 & $6.56 ; 48.24$ & 0.015 \\
\hline Rio Branco (AC) & 7.78 & $1.87 ; 13.69$ & 0.015 & 16.19 & $3.32 ; 29.06$ & 0.019 \\
\hline Rio de Janeiro (RJ) & 14.17 & $1.76 ; 26.59$ & 0.029 & 43.16 & $11.86 ; 74.47$ & 0.012 \\
\hline Salvador (BA) & 14.82 & $1.08 ; 28.55$ & 0.037 & 21.62 & $7.15 ; 36.09$ & 0.008 \\
\hline São Luís (MA) & 23.53 & $2.38 ; 44.69$ & 0.033 & 33.81 & $8.21 ; 59.40$ & 0.015 \\
\hline São Paulo (SP) & 12.37 & $2.26 ; 22.48$ & 0.021 & 50.20 & $10.27 ; 90.14$ & 0.019 \\
\hline Teresina (PI) & 42.88 & $8.66 ; 77.11$ & 0.019 & 55.42 & $20.26 ; 90.59$ & 0.006 \\
\hline Vitória (ES) & 15.01 & $4.66 ; 25.36$ & 0.009 & 31.28 & $-1.28 ; 63.84$ & 0.058 \\
\hline
\end{tabular}

95\%Cl: 95\% confidence interval; AC: Acre; AL: Alagoas; AM: Amazonas; AP: Amapá; BA: Bahia; CE: Ceará; ES: Espírito Santo; GO: Goiás; MA: Maranhão; MG: Minas Gerais; MS: Mato Grosso do Sul; MT: Mato Grosso; PA: Pará; PB: Paraíba; PE: Pernambuco; PI: Piauí; PR: Paraná; RJ: Rio de Janeiro; RN: Rio Grande do Norte; RO: Rondônia; RR: Roraima; RS: Rio Grande do Sul; SC: Santa Catarina; SE: Sergipe; SP: São Paulo; TO: Tocantins. Note: in bold p-value $<0.05$. 
Considering the percentage composition of health resources, Figure 2 shows the proportions of health revenues from federal resource transfers (blue) and expenditures with municipal resources (yellow). In most capitals (53.8\%), the federal revenue transfers represented more than 50\% of the values allocated to health over the years. Boa Vista (Roraima State), Macapá, Rio de Janeiro, and Vitória were the capitals with the highest variability in the composition of health resources from 2008 to 2018.

Table 3 presents the correlation between per capita revenue by federal transfers and per capita expenditure with municipal resources. All capitals presented a statistically significant positive correlation (all $\mathrm{r}>0.850$ and all $\mathrm{p}<0.001)$. The lowest correlation coefficient was found for Macapá $(\mathrm{r}=$ 0.860), whereas the highest coefficient was found for Fortaleza $(r=0.997)$.

\section{Figure 2}

Proportions of health revenues from federal resource transfers and municipal health expenses per inhabitant/year. Brazil, 2008 -2018.
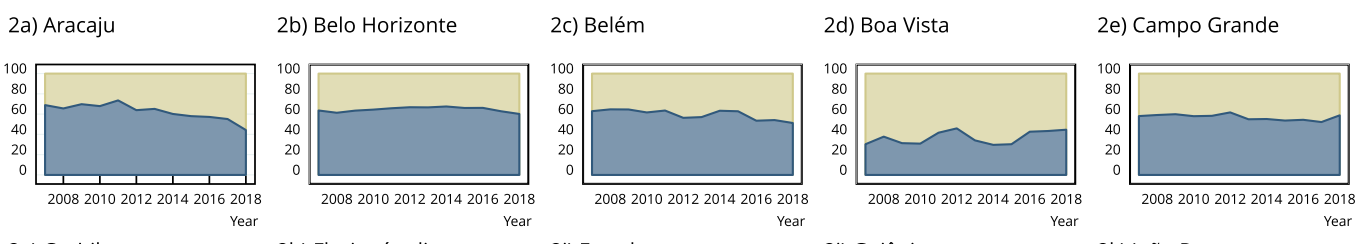

2f) Cuiabá

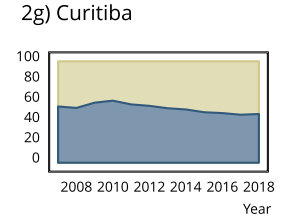

2h) Florianópolis

2i) Fortaleza

2j) Goiânia

2k) João Pessoa
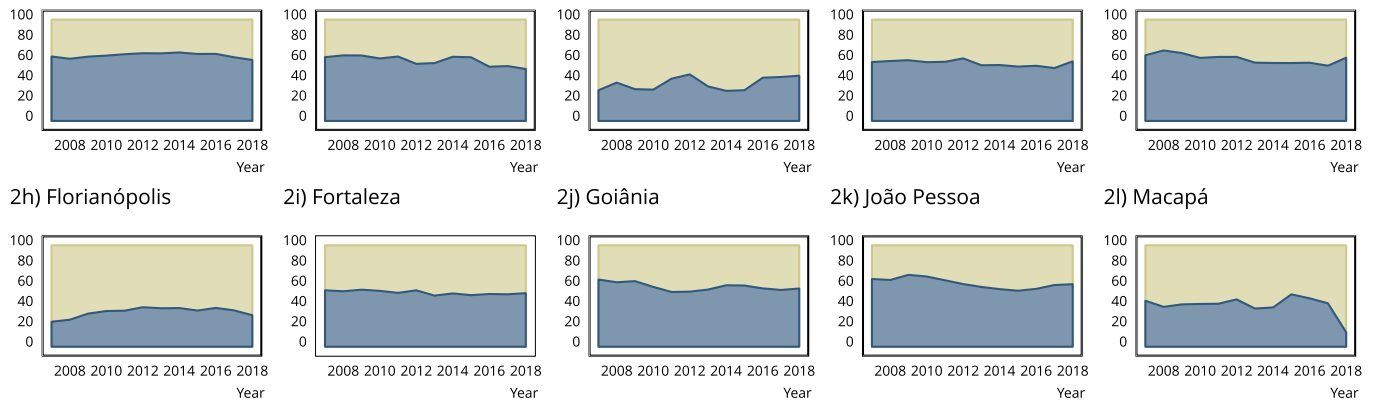

21) Macapá

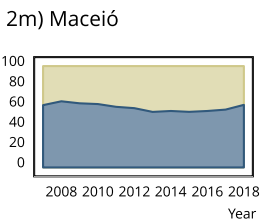

2n) Manaus

2o) Natal

2p) Palmas

2q) Porto Alegre
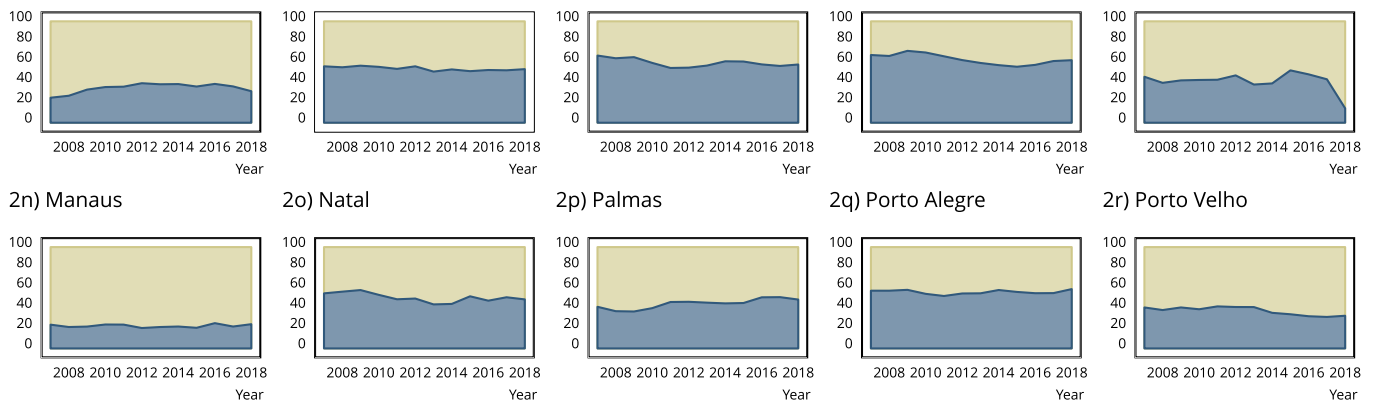

2s) Recife

2t) Rio Branco
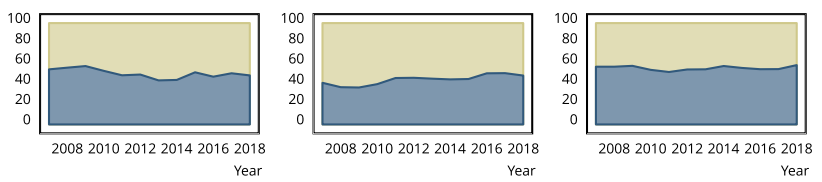

2r) Porto Velho

2u) Rio de Janeiro

2v) Salvador

2w) São Luís
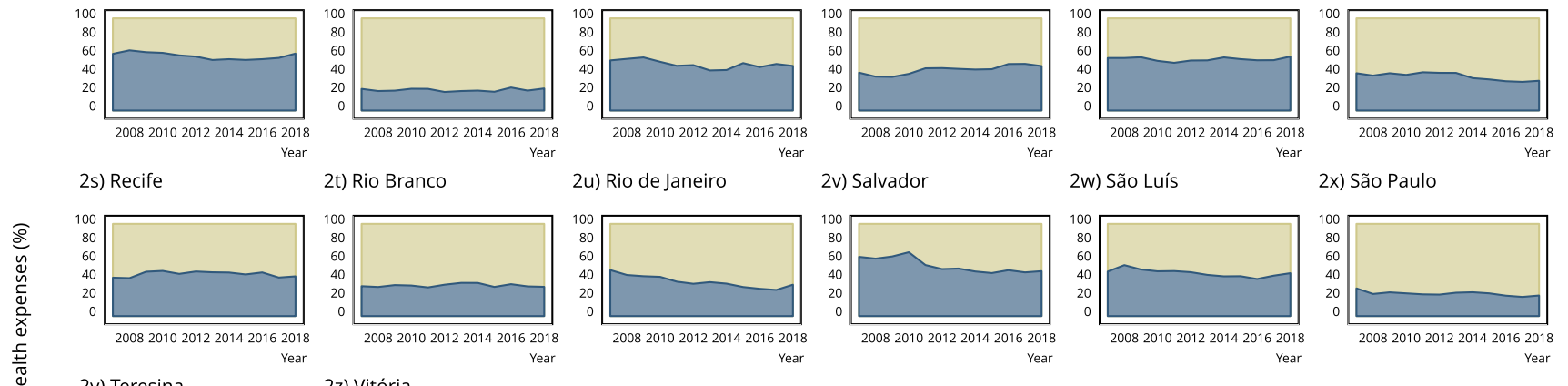

2x) São Paulo

2z) Vitória
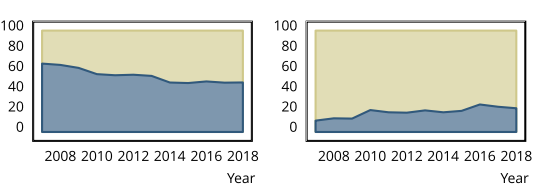

Municipality health expenses

Federal transfers

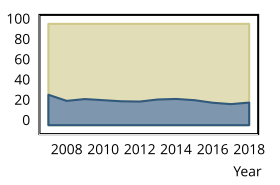


Table 3

Analysis of the correlation between the health funding from federal transfers (per capita) and health expenditures by the cities (per capita). Brazil, 2008-2018.

\begin{tabular}{|c|c|c|}
\hline Capital & Correlation coefficient ( $r$ ) & p-value * \\
\hline Macapá (AP) & 0.860 & $<0.001$ \\
\hline Aracaju (SE) & 0.899 & $<0.001$ \\
\hline Vitória (ES) & 0.963 & $<0.001$ \\
\hline Boa Vista (RO) & 0.976 & $<0.001$ \\
\hline Cuiabá (MT) & 0.976 & $<0.001$ \\
\hline Rio de Janeiro (RJ) & 0.977 & $<0.001$ \\
\hline João Pessoa (PB) & 0.978 & $<0.001$ \\
\hline Salvador (BA) & 0.978 & $<0.001$ \\
\hline Belém (PA) & 0.978 & $<0.001$ \\
\hline Florianópolis (SC) & 0.978 & $<0.001$ \\
\hline Palmas (TO) & 0.983 & $<0.001$ \\
\hline Porto Velho (RR) & 0.985 & $<0.001$ \\
\hline Natal (RN) & 0.987 & $<0.001$ \\
\hline Maceió (AL) & 0.987 & $<0.001$ \\
\hline Campo Grande (MS) & 0.989 & $<0.001$ \\
\hline São Luís (MA) & 0.989 & $<0.001$ \\
\hline Goiânia (GO) & 0.990 & $<0.001$ \\
\hline Teresina (PI) & 0.990 & $<0.001$ \\
\hline Curitiba (PR) & 0.992 & $<0.001$ \\
\hline Manaus (AM) & 0.992 & $<0.001$ \\
\hline Porto Alegre (RS) & 0.993 & $<0.001$ \\
\hline Belo Horizonte (MG) & 0.993 & $<0.001$ \\
\hline Recife (PE) & 0.994 & $<0.001$ \\
\hline Rio Branco (AC) & 0.995 & $<0.001$ \\
\hline São Paulo (SP) & 0.996 & $<0.001$ \\
\hline Fortaleza (CE) & 0.997 & $<0.001$ \\
\hline
\end{tabular}

AC: Acre; AL: Alagoas; AM: Amazonas; AP: Amapá; BA: Bahia; CE: Ceará; ES: Espírito Santo; GO: Goiás; MA: Maranhão; MG: Minas Gerais; MS: Mato Grosso do Sul; MT: Mato Grosso; PA: Pará; PB: Paraíba; PE: Pernambuco; PI: Piauí; PR: Paraná; RJ: Rio de Janeiro; RN: Rio Grande do Norte; RO: Rondônia; RR: Roraima; RS: Rio Grande do Sul; SC: Santa Catarina; SE: Sergipe; SP: São Paulo; TO: Tocantins.

* p-value $<0.05$.

\section{Discussion}

The public health funding standards established in Brazil expose the SUS to underfunding and inequality in the distribution of resources in certain urban centers. The trend analysis of public health revenues and expenditures showed an annual increase of both indicators, from federal transfers and municipal resources. We found discrepancies in the composition of budgets among the capitals, especially when compared to the health revenues obtained from federal transfers.

In 2018, the highest differences were found between Macapá and Cuiabá, with collections of BRL 19.81 and BRL 919.68 per inhabitant, respectively. We observed that such funding inequalities are not limited to Brazilian capitals. A study performed with municipalities in the region of Rota dos Bandeirantes showed that the revenue available to Barueri (São Paulo State) was almost 10 times higher than the revenue of Carapicuíba (São Paulo State) 10. In turn, a study developed in large urban centers in the State of São Paulo showed a smaller difference (1.85 times higher for Campinas - BRL 377.74, compared to Osasco - BRL 204.08) 9. The difference in resource distributions among Brazilian states 
and municipalities may aggravate the inequalities in health care access, and the solution depends on establishing a new financing standard with criteria based on the theoretical principles of SUS. The literature described additional evidence of inequalities in federal distribution. A study developed in the State of Bahia found large inequalities between municipalities, and the highest resource concentrations were found in large cities 18 .

In 2008, similar to 2018, the lowest SUS transfer value was concentrated in the Northern region of Brazil, specifically in Manaus, with BRL 22.30 per capita. This may be explained by the fact that Macapá, Manaus, Rio Branco (Acre State), and Porto Velho (Rondônia State) have an annual variation of federal transfer revenues below the values found for the rest of the country. The systematically lower transfer to this region only reinforces the inequality hypothesis between the different Brazilian regions, considering that this is one of the poorest regions in the country. Notably, the decentralization process of the SUS occurred heterogeneously across Brazilian municipalities. The municipalization of federal resources directed to health actions and services was proportional to the population size and health services already installed in the cities ${ }^{19}$. These criteria are not sufficient to assure the effective development of local health networks and do not reduce regional inequalities 19.

Moreover, the low systematization in the process of resource allocation 20 affects the quality of actions and services provided by SUS, promoting the argument of those who understand that public health should only be dedicated to primary care or only directed to the poorest segments of the population 21. Financial resources are not the only factor affecting the quality of health actions 11. Qualified and efficient management 11 , as well as adequate human resources training and capacity installed 9 , can be cited as variables related to the efficiency of SUS services.

Regarding health expenditures with the capitals' resources, in 2018, Macapá was the capital that committed the least city expenditures per inhabitant, BRL 120.17. When analyzing the health expenses of the Northern states, Amapá was the sixth out of the seven states from the region with the lowest expenses. It is expected that the SUS transfer values could complement the funding of health actions by the cities, considering their financial and epidemiological needs, aiming to achieve an equitable public health resource distribution 5 . Therefore, cities with low availability of per capita resources should receive higher complementation by federal resources 5 , which did not occur in Macapá. However, the opposite is also possible - capitals that receive limited federal resources could also complement health expenditures by capital funding. However, the literature is limited when analyzing factors related to it.

As for the percentage of funding according to the sources, in approximately half of the capitals, the values allocated for health came especially from federal transfers. The high percentage of federal transfers for SUS actions confirms the importance of such transfers to compose the capital's health budget, but also their high level of dependency on federal transfers, which directly affects the quality and availability of health services to citizens. In this sense, it is important to observe that, in certain Brazilian regions, the health transfers from federal resources to the cities reached $82 \% 8$. These differences have greater relevance when analyzing the management of hospital services, in which the development is mainly influenced by tax collection capacity, population size 22, and the interests of different players involved in the management of SUS 20. Moreover, in the first decades of the SUS, no clear norms were published to guarantee the organization of hospital services in integrated and coordinated systems 20 .

State capitals are regional references for hospitals and specialized care. It is important to consider that there was a higher heterogeneity in the municipalization process of these services, producing different management models. Thereby, some states did not experience the complete municipalization of services, leaving to state administration the responsibility for managing specialized care and hospital services, as in the State of São Paulo 23. This heterogeneity can represent a limitation for understanding the regional inequalities in the distribution of financial resources, considering that some states do not make financial transfers referring to hospital services to the cities. However, it considers that state resources correspond to the smallest part of SUS funding 24,25, which allowed analysis and interpretation.

Analyzing the correlation between SUS transfer revenues and expenditures with municipal resources, both per capita, we observe a proportionality between the two parameters, that is, the higher the federal transfer revenues, the higher the health expenditures funded by the capitals. It is 
important to highlight that the correlations observed were strong and directly proportional. The simultaneous increase of SUS transfers and municipal expenditures may represent the adherence to federal policies, which also includes municipal investments (co-funding). However, this concomitant increase does not necessarily express an expansion or improvement in the health care network, considering that personnel and structural expenditures grow above inflation, representing higher expenditures to maintain a similar structure 26 .

The discussion on the SUS budget should be separated from the issue of public health management, aiming at the efficiency of public expenses. In this sense, although cities with higher revenue available and higher per capita expenses reach the best health indicator results, some cities with small structures have also reached good results, highlighting the management efficiency of their structures 11 . Thus, one of the limitations of this study was not assessing the level of technical efficiency in the health management of Brazilian capitals to understand the applicability of their resources and federal funding, as well as health priorities and the main demands of each capital. Another limitation is related to the data source: SIOPS is a system that uses data entered by each government instance (federal, state, and municipal) which is not free of inconsistencies. The health budget analysis in Brazilian capitals allowed understanding the origin and per capita distribution of financing at a national level, showing the various forms of inequality in the transfer of funds in all regions of the country. These inequalities are relevant and may work to extend the inequalities in health care access. Further studies with national coverage are still required to assess the quality of services offered by the capitals and the equity in financial resource distribution, potentially including assistance indicators of the 26-Brazilian capitals.

When observing the results obtained in this study, it is eminent the concern with the future of public health actions and services, considering the budget issue. The Brazilian legislation determines minimum values to be invested in health by federal, state, and municipal governments 27 . However, it should be considered the austerity policy imposed on public expenses (spending ceiling), enforced since 2017, which states that the growth in public expenses cannot overcome the increase in inflation. In this context, between 2003 and 2015, the expenses for public health services and education, considered important for developing and improving the quality of life in Brazil, have grown an average of $6.3 \%$ per year above the inflation 26 . Hence, the trend is that within a few years, public expenses will have lower participation in the economy, and the resources that fund public services will be limited. We wmphasize that the reduction in expenses affects public policies that directly benefit lower social classes, which depend more on services offered by the State, with a tendency to worsen their quality of life and increase social inequalities in Brazil.

\section{Conclusions}

We may conclude that there was a real increase in SUS transfers and municipal resources in almost all capitals studied. However, high heterogeneity was identified among the distributions of SUS resources over the years studied. This difference could be explained first by the municipalization strategy used for federal transfers, which favored cities with higher population size and health service structures previously organized. Another explanation also related to the decentralization process is the management and financing of hospital services, which promoted heterogeneous relationships between states and cities and suggest different financial contributions from the states.

The results of this study indicate that lower transfer volumes were made to Brazilian capitals with lower income, which may further increase the inequalities between rich and poor regions in the country. The discussion on the funding of public policies is an important topic to identify gaps that can contribute to the quality of the actions offered to the population. However, funding is not the only factor affecting the quality of health services. Aspects related to the management of the health network and the background of human resources working in SUS must to be considered.

We highlight that the decentralization process of SUS and other variables that also affect financial distribution were not included in this study. Thus, other financial indicators of SIOPS can be the aim of future studies, helping to understand the financial distribution in the Brazilian health policy. 


\section{Contributors}

V. H. F. P. Oliveira contributed on the concept and design, acquisition of data, analysis, and interpretation of data and drafting of the manuscript. M. B. Oliveira collaborated on the acquisition of data, analysis, and interpretation of data and drafting of the manuscript. C. Blumenberg participated on the data statistical analysis and drafting of the manuscript. A. M. Herval participated on the analysis and interpretation of data and drafting of the manuscript. L. R. Paranhos contributed on the concept and design, drafting of the manuscript and critical revision of the paper for important intellectual content.

\section{Additional informations}

ORCID: Vinícius Henrique Ferreira Pereira de Oliveira (0000-0002-4177-9888); Millena Barroso Oliveira (0000-0001-5878-781X); Cauane Blumenberg (0000-0002-4580-3849); Álex Moreira Herval (0000-0001-6649-2616); Luiz Renato Paranhos (0000-0002-7599-0120).

\section{Acknowledgments}

This study was financed in part by the Brazilian Graduate Studies Coordinating Board (CAPES; Finance Code 001). Furthermore, we are thankful for the support of Brazilian National Research Council (CNPq), and Minas Gerais State Research Foundation (FAPEMIG).

\section{References}

1. Blog da Saúde. SUS: 27 anos transformando a história da saúde no Brasil. http://www. blog.saude.gov.br/35647 (accessed on 23/ Aug/2020).

2. Ministério da Saúde. Carta dos direitos dos usuários da saúde. 3a Ed. Brasília: Ministério da Saúde; 2011. (Série E. Legislação de Saúde).

3. Ugá MAD, Santos IS. Uma análise da progressividade do financiamento do Sistema Único de Saúde (SUS). Cad Saúde Pública 2006; 22:1597-609.

4. Mendes A. A longa batalha pelo financiamento do SUS. Saúde Soc 2013; 22:987-83.

5. Mendes A, Leite MG, Marques RM. Discutindo uma metodologia para a alocação equitativa de recursos federais para o Sistema Único de Saúde. Saúde Soc 2011; 20:673-90.

6. Marinho A. Avaliação da eficiência técnica nos serviços de saúde nos municípios do estado do Rio de Janeiro. Revista Brasileira de Economia 2003; 57:515-34.

7. Santo ACGE, Fernando VCN, Bezerra AFB. Despesa pública municipal com saúde em Pernambuco, Brasil, de 2000 a 2007. Ciênc Saúde Colet 2012; 17:861-71.

8. Rosa MRR, Coelho TC. O que dizem os gastos com o Programa Saúde da Família em um município da Bahia? Ciênc Saúde Colet 2012; 16:1863-73.

9. Espírito Santo ACG, Tanaka OY. Financiamento, gasto e oferta de serviços de saúde em grandes centros urbanos do estado de São Paulo (Brasil). Ciênc Saúde Colet 2011; 16: 1875-85.

10. Santos Neto JA, Mendes AN, Pereira AC, Paranhos LR. Análise do financiamento e gasto do Sistema Único de Saúde dos municípios da região de saúde Rota dos Bandeirantes do estado de São Paulo, Brasil. Ciênc Saúde Colet 2017; 22:1269-80.

11. Santos Neto JA, Mendes AN, Pereira AC, Paranhos LR. Avaliação da eficiência técnica em saúde dos municípios da região de saúde Rota dos Bandeirantes do estado de São Paulo, Brasil. Ciênc Saúde Colet 2019; 24:3793-803.

12. Conselho Nacional de Secretários de Saúde. O financiamento da saúde. Brasília: Conselho Nacional de Secretários de Saúde; 2011.

13. Ministério da Saúde. Entendendo o SUS. Brasília: Ministério da Saúde; 2006.

14. Malta M, Cardoso LO, Bastos FI, Magnanini MMF, Silva CMFP. Iniciativa STROBE: subsídios para a comunicação de estudos observacionais. Rev Saúde Pública 2010; 44:559-65.

15. Ministério da Saúde. Sistema de Informações sobre Orçamentos Públicos em Saúde. SIOPS. http://www.portalsaude.saude.gov.br/index. $\mathrm{php} / \mathrm{o}-\mathrm{ministerio/principal/siops} \mathrm{(accessed} \mathrm{on}$ 23/Aug/2020). 
16. Instituto Brasileiro de Geografia e Estatística. IPCA - Índice de Preços ao Consumidor Amplo. http://www.ibge.gov.br/estatisticas/ economicas/precos-e-custos/9256-indicenacional-de-precos-ao-consumidor-amplo. html? =\&t=o-que-e (accessed on 23/Aug/2020).

17. Instituto Brasileiro de Geografia e Estatística. Estimativas da população. http:// www.ibge.gov.br/estatisticas/sociais/popu lacao/9103-estimativas-de-populacao.html? edicao $=22367 \& \mathrm{t}=$ resultados $($ accessed on $23 /$ Aug/2020).

18. Teles AS, Coelho TCB, Ferreira MPDS. Sob o prisma da equidade: financiamento federal do Sistema Único de Saúde no estado da Bahia. Saúde Soc 2016; 25:786-99.

19. Simão JB, Orellano VIF. Um estudo sobre a distribuição das transferências para o setor de saúde no Brasil. Estudos Econômicos (São Paulo) 2015; 45:33-63.

20. Carpanez LR, Malik AM. O efeito da municipalização no sistema hospitalar brasileiro: os hospitais de pequeno porte. Ciênc Saúde Colet 2021; 26:1289-98.

21. Marques RM, Mendes A. A problemática do financiamento da saúde pública brasileira de 1985 a 2008. Economia e Sociedade 2012; 21:345-62.

22. Arretche M, Marques E. The municipalization of health care policies in Brazil: regional differences, the voting power and government strategies. Ciênc Saúde Colet 2002; 7:455-79.
23. Spedo SM, Pinto NRDS, Tanaka OY. The intramunicipal regionalization of the Brazilian National Health System (SUS): a case study in the city of São Paulo (SP), Brazil. Saúde Soc 2010; 19:533-46.

24. Leite VR, Lima KC, Vasconcelos CMD. Funding, public spending and management of health resources: the current situation in a Brazilian State. Ciênc Saúde Colet 2012; 17:1849-56.

25. Pinafo E, Carvalho BG, Nunes EFPA. Decentralization of health management: the path traveled to date, problematic points and prospects. Ciênc Saúde Colet 2016; 21:1511-24.

26. Blumé BA. Como funciona o teto de gastos públicos? Politize! 2021; 21 oct. http://www. politize.com.br/teto-de-gastos-publicos-info grafico.

27. Blumé BA. Quanto o governo investe em saúde e educação? Politize! 2016; 13 jul. http://www. politize.com.br/quanto-governo-investe-sau de-educacao/. 


\section{Resumo}

O estudo teve como objetivo analisar parte dos recursos utilizados para financiar ações de saúde pública nas 26 capitais brasileiras entre 2008 e 2018. O estudo ecológico de tendências temporais envolveu indicadores de receitas e gastos fornecidos pelo Sistema de Informação sobre Orçamento Público em Saúde (SIOPS). Os valores foram deflacionados com base no Índice de Preços ao Consumidor Amplo de 2018 no Brasil para permitir a comparação ao longo dos anos. A variação anual média dos investimentos em saúde, em Reais (BRL), foi avaliada com o uso de regressões lineares. Os coeficientes de correlação de Pearson foram estimados entre as receitas e gastos federais com os recursos das capitais. Todas as capitais apresentaram correlações estatisticamente positivas com a origem do recurso orçamentário investido em saúde. O menor coeficiente foi encontrado na cidade de Macapá (Amapá) $(r=0,860)$, e o mais alto em Fortaleza (Ceará) $(r=0.997)$. Belo Horizonte (Minas Gerais) foi a capital com o maior aumento anual em transferências federais (cerca de BRL 67,91 por ano) e Teresina (Piauí) apresentou o maior aumento anual nos gastos em saúde (cerca de BRL 55,42 por ano). Houve um aumento real nas transferências no Sistema Único de Saúde (SUS) e nos recursos municipais em quase todas as capitais, mas ainda persistem desigualdades na distribuição dos recursos financeiros entre as capitais brasileiras das cinco regiões. O financiamento da saúde é afetado pela municipalização do SUS, e não é o único fator que afeta o acesso e a qualidade dos serviços de saúde.

Investimentos em Saúde; Qualidade da Assistência à Saúde; Sistema Único de Saúde

\section{Resumen}

El objetivo fue analizar la parte de recursos financieros utilizados para financiar acciones de salud públicas en 26 capitales brasileñas, entre $2008 y$ 2018. Se trata de un estudio ecológico de tendencia temporal, implicando indicadores de ingresos $y$ gastos proporcionados por el Sistema de Información sobre el Presupuesto Público para Salud (SIOPS). Se deflactaron los valores basados en el Índice de Precios al Consumidor, ampliado de 2018 en Brasil, para permitir la comparación a lo largo de los años. La variación anual media de inversiones en salud, en Reales brasileños (BRL), fue evaluada usando regresiones lineales. Se estimaron los coeficientes de correlación de Pearson entre los ingresos y gastos federales, respecto a los recursos de las capitales. Todas las capitales presentaron estadisticamente correlaciones positivas significativas respecto a la fuente presupuestaria originaria invertida en salud. El coeficiente más bajo se encontró en la capital de Macapá (Amapá) $(r=0.860)$ y el más alto en Fortaleza (Ceará) ( $r=0.997)$. Belo Horizonte (Minas Gerais) fue la capital con el incremento anual más alto en transferencias federales (cerca de BRL 67.91 por año) $y$ Teresina (Piauí) presentó el incremento anual más alto en gastos de salud entre todas las capitales (sobre BRL 55.42 por año). Hubo un incremento real de transferencias en el Sistema Único de Salud brasileño (SUS), así como recursos municipales en casi todas las capitales, pero existen todavía inequidades en la distribución de recursos financieros entre las capitales brasileñas de diferentes regiones. La financiación de la salud está afectada por la municipalización del SUS, y no es el único factor que afecta al acceso y calidad de los servicios de salud.

Inversiones de Salud; Calidad de la Atención de Salud; Sistema Único de Salud
Submitted on $28 /$ Oct $/ 2020$

Final version resubmitted on 17/May/2021

Approved on 25/Jun/2021 